\title{
The latest is not always the greatest
}

\author{
Freddie $\mathrm{H}^{\mathrm{Fu}}{ }^{1}$
}

Published online: 11 January 2022

(c) The Author(s) under exclusive licence to European Society of Sports Traumatology, Knee Surgery, Arthroscopy (ESSKA) 2022

\begin{abstract}
"Now what is innovation? It means, it is knowledge, it is attitude, it is adoption or rejection, implementation, and confirmation of what's new or changed. Of course, innovation is very good! In the last 100 years, these big three (anesthesia, antisepsis, and Xray/MRI) enabled us to be where we are today, and I am sure in the next century all these interesting concepts (genomics, imaging, and big data) will carry medicine, in a big way.

Dr. [Philip] Hench ${ }^{1}$ was a medical student at the University of Pittsburgh. He went on to win the Nobel Prize at the Mayo Clinic for the discovery of steroids and their use in treating rheumatoid arthritis. There was a distinguished alumni award named after Hench in Pittsburgh, and some of the winners are famous, like Dr. [Henry] Mankin [1] ${ }^{2}$; Dr.
\end{abstract}

[Robert] D'Ambrosia ${ }^{3}$; and I was honored to be one of the winners too. Another famous person from Pittsburgh is Peter Lauterbur. ${ }^{4} \mathrm{He}$ was a physics $\mathrm{PhD}$ student, and in the Big Boy restaurant, ${ }^{5}$ he had the idea of an MRI model - he scribbled on a table napkin in Pittsburgh! He went on to Long Island, Stony Brook, and Illinois and won the Nobel Prize together with Sir Peter Mansfield ${ }^{6}$ from London. Except Peter [Lauterbur] never filed a patent-I had a chance to talk with him before he passed away and he felt very good about it. He said 'medicine is meant to help people! It is OK to make some money but it's not the key.'

\begin{abstract}
${ }^{1}$ Philip Hench, M.D. (February 28, 1896-March 30, 1965) was an American physician who received his medical training at the United States Army Medical Corps and the University of Pittsburgh, before joining Mayo Clinic as faculty. Hench, along with his Mayo Clinic co-worker Edward Calvin Kendall and Swiss chemist Tadeus Reichstein was awarded the Nobel Prize for Physiology or Medicine in 1950 for the discovery of the hormone cortisone, and its application for the treatment of rheumatoid arthritis.

${ }^{2}$ Henry J. Mankin, M.D. (October 9, 1928-December 22, 2018) was a Pittsburgh Native, earning both his undergraduate and medical education at the University of Pittsburgh. He went on to become the Edith M. Ashley Professor of Orthopaedics Emeritus at Harvard Medical School and Chair of the Department of Orthopaedic Surgery at Massachusetts General Hospital. His pioneering research on cartilage and focus on education in Orthopaedic Surgery only highlight the tremendous impact he has had in Orthopaedics.
\end{abstract}

Freddie H. Fu

ffu@upmc.edu

1 UPMC Freddie Fu Sports Medicine Center, University of Pittsburgh, 3200 South Water Street, Pittsburgh, PA 15203, USA

\footnotetext{
${ }_{3}$ Robert D'Ambrosia, M.D. attended the University of Pittsburgh for" both medical education and residency training in orthopaedic surgery. He was honored by the American Academy of Orthopaedic Surgeons (AAOS) with the 2014 Diversity Award during the annual meeting of the group in New Orleans. Currently, he is professor and chair of the department of orthopedics at the University of Colorado.

${ }^{4}$ Peter Lauterbur, Ph.D. (May 6, 1929-March 27, 2007) was an American chemist, earning his Ph.D. in 1962 from the University of Pittsburgh. He shared the Nobel Prize in Physiology or Medicine in 2003 with Peter Mansfield for his work which made the development of magnetic resonance imaging (MRI) possible.

${ }^{5}$ Big Boy Restaurant Group, LLC is an American restaurant chain headquartered in Warren, Michigan, in Metro Detroit. Frisch's Big Boy Restaurants is a restaurant chain with its headquarters in Cincinnati, Ohio. The Big Boy name, design aesthetic, and menu were previously licensed to a number of regional franchisees. Big Boy was started as Bob's Pantry in 1936 by Bob Wian in Glendale, California. The restaurants became known as "Bob's", "Bob's Drive-Ins", "Bob's, Home of the Big Boy Hamburger", and (commonly as) Bob's Big Boy.

${ }^{6}$ Sir Peter Mansfield (9 October 1933-8 February 2017) was an English physicist who was awarded the 2003 Nobel Prize in Physiology or Medicine, shared with Paul Lauterbur, for discoveries concerning Magnetic Resonance Imaging (MRI). In 1987, he was elected Fellow of the Royal Society (FRS).
} 


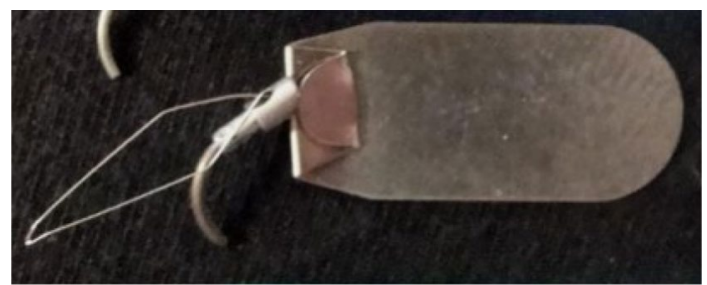

Fig. 1 MITEK G1 Suture Anchor

Now, in sports medicine, arthroscopy is the key to improving the outcomes of surgery today. When it started, it created a lot of controversy. For example, in ACL surgery, it became fast and efficient, but initially with the wrong anatomy. Now, once in a lifetime you may hit a homerun by a big discovery like Professor Barry Marshall ${ }^{7}$ from Perth, Australia, who challenged the concept of gastric ulcers-not [caused] by stress or other means, but by bacteria. He was able to prove it in his studies.

Product development is important. So, we need to move along, but on the other hand, it's a double-edged sword. Many of these products may not work or may even harm people. I had the experience back in the early 1980's when I was a young faculty, and Dr. [John] Richmond ${ }^{8}$ from Boston called me and said that a few Massachusetts Institute of Technology (M.I.T.) scientists had developed a way to anchor soft tissue to bone. The two scientists [Jim Nicholson and Arthur Collias], M.I.T. graduates, filed a patent on this MITEK anchor-the "tech from M.I.T." - this was the G1 anchor (Fig. 1). Dr. [John] Richmond 7 and I did the clinical work, and I did all the biomechanics to show that the anchor is strong and safe too [2]. It was approved by the FDA in 1989. The only thing is, at that time, Dr. [John] Richmond and myself were not that well-known, so they needed to find a well-known surgeon-and well-known patients- to

\footnotetext{
$\overline{7}$ Barry Marshall, M.D. is an Australian physician, Nobel Prize Laureate in Physiology or Medicine, Professor of Clinical Microbiology and Co-Director of the Marshall Centre ${ }^{[[4]]}$ at the University of Western Australia. Dr. Marshall along with Robin Warren showed that the bacterium Helicobacter pylori (H. pylori) plays a major role in causing many peptic ulcers, challenging decades of medical doctrine holding that ulcers were caused primarily by stress, spicy foods, and too much acid. This discovery has allowed for a breakthrough in understanding a causative link between Helicobacter pylori infection and stomach cancer.

${ }^{8}$ John Richmond, M.D., currently serves as Medical Director for Network Development at New England Baptist Hospital (NEBH) and has previously served as Chairman of Orthopaedics at NEBH for over a decade as well as Professor of Orthopaedic surgery at Tufts University School of Medicine. He has served as President of the Eastern Orthopaedic Association. His research focuses on ligament and cartilage injury, biology, and healing, for which he has received the O'Donoghue Sports Injury Research Award (1995) and the Cabaut Memorial Basic Science Research Award (2007).
}

promote the anchor. So, they found Dr. Frank Jobe, ${ }^{9}$ who is a very kind gentleman, and Orel Hershiser, ${ }^{10}$ who was a very famous pitcher in American baseball.

\section{[Dr. Frank Jobe Interview]}

'Well, the first time I saw an anchor was at an academy meeting and a small company, who had a man standing behind a card table and a little box of anchors, and I looked at him and thought, man you know, that would work good in the shoulder. And this is an anchor that Freddie Fu had done the basic work on, and this was the first time they were being shown to the public. So, he gave me a few, just a handful, and I took them home and did a couple of cases, they worked great, and about that time, Orel Hershiser, our Cy Young award-winning pitcher for that year, came in with a dislocated shoulder...... What was I going to do with it?....I said, I've got just the operation!' [3] (Fig. 2).

So, with the success of this surgery by Dr. [Frank] Jobe, the anchor sales sky-rocketed. In fact, there are so many anchors, now developed by many companies, and MITEK was sold to Johnson \& Johnson for \$129 million dollars. So this, to me, is "The American Dream". Personally, I do not benefit anything from it because I just performed the basic science study. I feel very good about this as a success story for a product.

Now, I want to make sure that everybody knows that in medicine, we always talk about positive results, and they get published very quickly. But negative results usually take a long time to be published. For example, I'm a Professor, and if I wrote everything negatively in my papers, I probably would not go that far. Generally, people want positive results. But of course, we have to be honest-if something is not right, we have to share this result with other people too.

\footnotetext{
$\overline{9}$ Frank Jobe, M.D. was (July 16, 1925-March 6, 2014) was an American orthopedic surgeon and co-founder of the Kerlan-Jobe Orthopaedic Clinic. He pioneered both elbow ligament replacement and major reconstructive shoulder surgery for baseball players. In 1974, Jobe performed the first "Tommy John surgery" on then-Los Angeles Dodgers pitcher Tommy John. Dr. Jobe also performed the first major reconstructive shoulder surgery on a Major League Baseball player in 1990, which allowed Dodger star Orel Hershiser to continue his career.

${ }^{10}$ Orel Hershiser is an American former baseball pitcher who played 18 seasons in Major League Baseball (MLB) from 1983 to 2000. Hershiser was a three-time All-Star and finished in the top five in Cy Young voting four times in his first six full seasons. Hershiser's most successful season came in 1988, when he set a major league record by pitching 59 consecutive innings without allowing a run. He helped lead the Dodgers to a championship in the 1988 World Series, and was named the National League (NL) Championship Series Most Valuable Player (MVP)and the World Series MVP. That season, he won the NL Cy Young Award and an NL Gold Glove Award.
} 


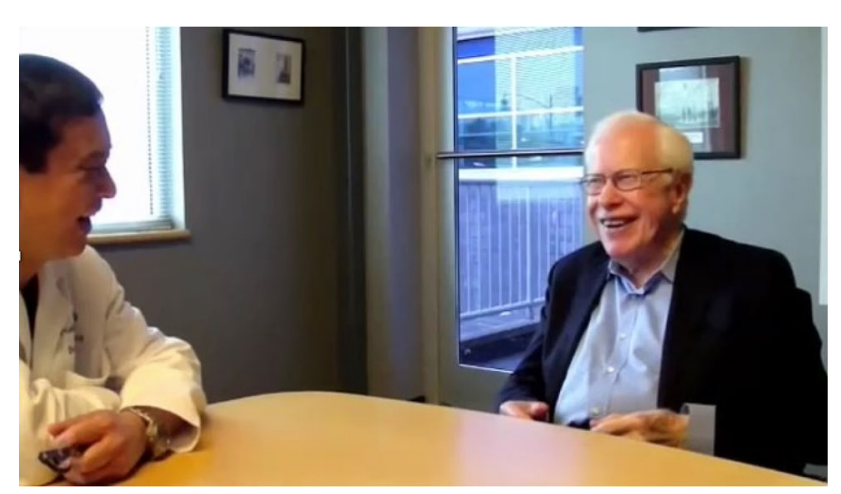

Fig. 2 Frank Jobe Discussing Suture Anchors with Freddie Fu

Now interestingly, if you look at an article from New York Times, they think many of these treatments in orthopaedics and cancer may be placebo or useless- $-30 \%$ orthopaedic and $50 \%$ of cancer treatment may not even affect the outcome [4].

There are a few products I want to share with you that we have come across the years, and they can be harmful to the patients.

Thalidomide was a sedative drug made in Germany and marketed as a very common antiemetic medication for pregnant women, supposed to help with morning sickness. But little did we know, this drug actually caused very harmful limb deformities in newborn babies. American congress actually requires safety testing nowadays for new drugs. This was the start of the Food and Drug Administration (FDA) and other similar programs in America. And it took many years until the company apologized to the victims. It is only about 10 years ago they did-it is in fact quite amazing [5]. Chymopapain is an enzyme that chemically digests the [intervertebral] discs. So, in the 1980's people got very enthusiastic about it and started to inject Chymopapain in the back. They claimed that by injection you will be able to eliminate surgery. In fact, in Pittsburgh, I remember in the 1980's, there were at least five or six clinics doing nothing but Chymopapain injections. Much like the stem cells, Platelet-Rich Plasma (PRP), that you see today. Unfortunately, Chymopapain doesn't quite work and may sometimes cause harmful effects. Eventually it took many years to remove it from the U.S. market.

Now, pain pumps were something that came from outpatient surgery in arthroscopy. In America, we like to send patients home (e.g. outpatient surgery). In order to do that, some companies think it is a good idea to use a pain pump to inject a local anesthetic into the joint during the first few post-operative days. This is not an FDA cleared indication, but people do this anyway. In fact, I remember a salesman came to me and said, 'hey Dr. Fu, you must do that.' Now, little did we know that this kind of local anesthetic can be harmful to some people, especially in the shoulder. So, I was in a meeting almost $15-20$ years ago and people started to talk about "I see cases of shoulder chondrolysis and these shoulders will wear out without infection." There were hundreds of cases in America resulting in lawsuits too. And many of these youngsters- 16 years old, 18 years old - now need a total shoulder replacement at a very young age.

Now, Vioxx is a very good inflammation medication-it is really helpful. It had peak sales of $\$ 2.5$ million, but the company actually knew there were some serious side-effects in people with an underlying risk of heart problems [6]. It caused death. As a result, this drug had to be pulled from the market. Which is sad because if they had disclosed the side-effect, maybe you could warn people—do not use it with a heart problem.

Avastin is a wonder drug for cancer. Essentially, it is supposed to work with chemotherapy to stop the growth of cancer. Interestingly, it was the most expensive drug at one time in the world. It had a good scientific basis and got a fast-track FDA approval. However, it was not effective for some cancers like breast cancer. It took years for it to be taken off the market and those patients are not being helped by this very expensive drug.

Now, is the latest always the greatest? This is the question. I have been in orthopaedics for more than 40 years and I would say I saw at least 200 products and surgical techniques that have come and gone. So, to show you a few examples right here; many of these are market driven by industry and not scientifically driven.

I was a first year resident, and I went to the American Academy of Orthopaedic Surgeons (AAOS) meeting in 1978 in San Francisco and Alfred Swanson, ${ }^{11}$ was a hand surgeon and he wrote about silastic implants in joints such as the radial head and other parts of the body [7]. He said that it works really well. Except, this young man called Bernard Morrey, ${ }^{12}$ who was a young resident at the Mayo clinic and I remember he went on stage and said 'this implant has very

\footnotetext{
11 Alfred Swanson, M.D. (April 16, 1923-April 27, 2016) pioneered the concept of using flexible implants for reconstruction of the small joints of the extremities and performed the first ever biocompatibility studies of silicone in bone in his orthopaedic research unit at Blodgett Memorial Medical Center in 1962. He served as Chief of Orthopaedic Surgery and Director of Orthopaedic Surgery Residency of the Blodgett (1954-79), Blodgett-Butterworth and Grand Rapids Hospitals Programs (1980-2001). He was Founding Director of Orthopaedic Research and Hand Surgery Fellowship at Blodgett Memorial Hospital (1962-2001).

12 Bernard Morrey, M.D. is the emeritus chair of the Department of Orthopedics, and the John and Posy Krehbiel Professor of Orthopaedic Surgery, at Mayo Clinic. He holds the academic rank of Professor of Orthopaedics at both Mayo Clinic and at the University of Texas Health Science Center, San Antonio.
} 
high failure' for cases done at the Mayo clinic [8]. I remember Professor [Alfred] Swanson just kind of spanked him and said you don't know what you are doing. Interestingly, five years later, no one used this silastic implant anymore.

Another Professor is Carl Brighton, ${ }^{13}$ who was convinced that electric stimulation was the key to healing of fractures. Together with a company, techniques to stimulate healing of fractures with electric stimulation devices were invented. And then in the 1970-1980's, it is really incredible, you had trials going on everywhere. Except now, you can hardly see anyone using it at all. So, again, there is not sufficient and conclusive evidence to have really good practice using electric stimulation when it comes to fracture healing.

Artificial ligaments were very attractive. I was an ACL surgeon and in the 1980's people would say, 'well you put the artificial ligament and other grafts in, and people can come back within weeks to play", and not like months. So, it sounded like a good idea. In fact, I put in 50 of these grafts and of the 50 I put in, I would say $90 \%$ of them failed and very few of them survived. Now the problem with this artificial ligament is basically, when they break, they create wear particles, and these wear particles can induce inflammation and osteolysis, which damages the knee. We have studied it in rabbit models and this was published in 1988 [9]. The mechanism is: wear particles enter the synovium, secrete cytokines, and cause joint damage.

Another artificial thing in the 1980's is the LAD—backed by a very powerful company too, and also working alongside consultants from various places. Very famous surgeons, which I respect tremendously. So, they want to put this artificial ligament on all the hamstrings, patellar tendons, or allografts, to enhance the healing and support. Now, it doesn't work. In fact, I was a traveling fellow in 1988 in Europe and almost every place I went was using it and doing trials on it. There were workshops all over the place. It went away eventually but now other companies have something called internal bracing - maybe not exactly the same but quite similar concept. So, all this invention comes back, maybe to haunt us in one way or another. Now this is interesting, Dr. Leo Pinczewski is one of the best-known surgeons in Australia and he wrote an article [10] to show that wear particles form in artificial ligaments and that people tried to sell again - many in Australia, Italy, France, and in China. So, history repeats itself after 20-30 years.

\footnotetext{
${ }_{13}$ Carl Brighton, M.D., Ph.D., (August 20, 1931- July 3, 2019) was a pioneer in using electricity to stimulate bone growth and fracture healing, and in investigating the epiphyseal growth plate. He received a multitude of awards including the Kappa Delta Award, the Shands Lectureship, and the MERIT award and SCOR Grant from the N.I.H.
}

Now, professor Sir John Charnley ${ }^{14}$-fantastic individual-I had a chance to see him talk and was really impressed. He was the type of guy who is always worried about every detail of his [prosthetic] joint and the results. And I think his [prosthetic] joint is still very good, in fact compared to even today's [prosthetic joints]—not way off. But now, companies will invent many new implant types-cementless, genderspecific, metal-on-metal. And the reason is like a car: I have a car, new engine, I have new things that you should buy-and they cost more money! They want to compete for a market share! Except, many of these companies typically have a profit margin of $20-30 \%$, and may need more to make ends meet. In your practice [as a physician], you don't get this $20-30 \%$ increase every year. In pharmaceuticals it is over $90 \%$ !

Barry Meier ${ }^{15}$ is an investigative reporter from the New York Times. And when he wrote his article, [11] it took months to do it. He talked about the metal-on-metal hipessentially how bad it is and how much failure it has and the reason was the company went around the FDA and tried to push this product in with a fast-track. And the opioid crisis, he exposed the fact that companies actually pay consultants, doctors themselves, to promote the use of [opioids]. Not just for pain relief in cancer patients, but for everyday use. So now this is the crisis in America, we have deaths, hundreds of deaths every day. The damage is already done and [we] may not ever recover for years.

Regenerative medicine is a very big term-essentially, it is a concept to replace tissue and organs. It is a good technology, good idea-you can have scaffolds or matrix seeded with stem cells, you replace muscle, bone, and cartilage [12, 13]. The first one we encountered in a big way was something called the S. I. S. [small intestine submucosa]-developed at Purdue university, it is called Restore. It is a matrix you use for patching the shoulder rotator cuff [14]. And in fact, about 20 years ago, it peaked sales at $\$ 80$ million and I actually attended some of the workshops. Except that a publication came out from Australia to show there are a lot of complications from this patch [15]. Cleveland Clinic had the same results - they had a clinical trial and they had to stop the trial because of the high complication rate with inflammation [16]. So again, this went away. In fact, the

\footnotetext{
14 Sir John Charnley, M.D. (1911-1982) was an English orthopaedic surgeon who pioneered total hip arthroplasty and thus is recognized as the founder of modern hip replacements. He also influenced generations of orthopaedic surgeons through his textbook on conservative fracture treatment which was first published in 1950. He received the Cameron Prize for Therapeutics of the University of Edinburgh (1974), the Lister Medal for his contributions to surgical science (1975), and was knighted in 1977.

15 Barry Meier is a writer and former New York Times journalist who wrote the 2003 non-fiction book Pain Killer: A Wonder Drug's Trail of Addiction and Death. His articles "have led to Congressional hearings and changes in federal laws.".
} 
company never took it away form the market. They will not advertise it now. Today, there are many patches available on the market right now-whether they work or not? Appear to have less complications at least.

Now, this is what I call a one-hit wonder-Paolo Macchiarini ${ }^{16}$ is a Spanish surgeon who did a stem cell-seeded synthetic trachea on a patient in Spain, and it was successful, at least he claimed so! My god, at that time it was incredible, nobody had done it. So, he was hired by the worldfamous Karolinska Institute in Stockholm, Sweden and he worked there. During his tenure there he performed several operations and wrote many papers and became very famous. In fact, he came to Pittsburgh to give a talk and did some surgeries in America too, in pediatric patients. Except that the result in Sweden was devastating. He was found to have scientific misconduct by researchers and the worst thing is it was covered up by the highest authorities from the Karolinska Institute. After a few years, the leadership, even the Nobel committee people, had to be removed from the Institute [17].

Now, BMP is a big discovery by Dr. Marshall Urist. ${ }^{17}$ $\mathrm{He}$ is a fantastic person and he was nominated for the Nobel prize three times. He never filed a patent for what was supposed to induce bone formation and cartilage formation. However, a company took over and called it Infuse [BMP2]. Interestingly, James Kang wrote an article [18] showing that the company had all kinds of consultants with them, but when the consultant wrote the article, usually 'no complications' was reported. We know the product works, but the big question is whether there are complications. If you are not a consultant with the company, ' $5-10 \%$ of complications' was reported. So as a result, company documents spurred new questions and the American government actually questioned the company's integrity because the company paid a total of $\$ 210$ million for about 15 surgeons as consultants for this product [19].

Credibility. You are a doctor, so you are credible. But more importantly, you have to maintain your integrity. This

\footnotetext{
16 Paolo Macchiarini is a Swiss-born Italian thoracic surgeon and former regenerative medicine researcher. He was previously considered a pioneer for using both biological and synthetic scaffolds seeded with patients' own stem cells as trachea transplants, Macchiarini was a visiting researcher at Sweden's Karolinska Institutet (KI) in 2010. Macchiarini has been accused of unethically performing experimental surgeries, even on relatively healthy patients, resulting in fatalities for seven of the eight patients who received one of his synthetic trachea transplants. Thus, he has became known for research fraud and manipulative behavior

17 Marshall Urist, M.D. (1914 - 2001) was a United States orthopedic surgeon working at University of California, Los Angeles who was best known for his discovery in 1965 of bone morphogenic protein. The Orthopaedic Research Society has given a "Marshall R. Urist Award" every year since 1997.
}

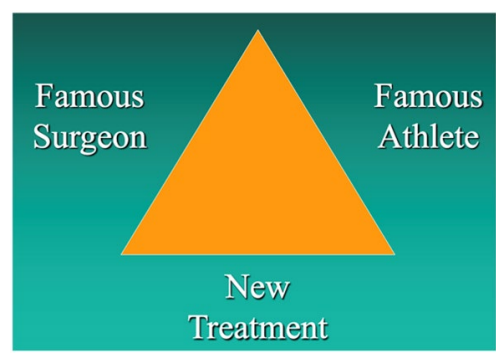

Fig. 3 Illustration of the orthopaedic triad described by Dr. John Bergfeld

is my speech when I was president of the American Orthopaedic Society for Sports Medicine (AOSSM) society in America. The other interesting fact is Paul Guyatt who I had a chance to meet at McMaster University in Ontario, talked about evidence based medicine back in 1992. We discussed how there are very good techniques that we can do very good clinical studies on and look at the results. Except things have changed now, people are smart, and they may use a Level 1 study but it might not really be Level 1 . So, this is why Dr. [Paul] Guyatt and his talk, when I was there with him, "is evidenced based really evidenced based"? You have to look at the fine print within the data. Now, this is the paradigm-improved patient outcomes require individual clinical expertise, patient values and expectations, and the best available clinical evidence. It takes a long time to do. This is a Level 1 study - if you want to do one, it can take years. And for most companies, this is too much time to achieve the results. Now, the quick way-as referenced by Dr. John Bergfeld ${ }^{18}$ —is the "Orthopaedic Triad"-famous surgeon, famous player, and a new treatment (Fig. 3). So that will get you to sell the product much faster.

Dr. [Henry] Mankin ${ }^{19}$ talked about the 'hattage effect.' He said that, in Britain, doctors 100 years ago, would see a patient, and they had no solution, but they would have a hat—and at the end [of a visit] they would say "good day

\footnotetext{
18 John Bergfeld, M.D. is an orthopaedic surgeon and sports medicine specialist in Cleveland, $\mathrm{OH}$. $\mathrm{He}$ is a senior surgeon in the Department of Orthopaedic Surgery at the Cleveland Clinic. He has been elected to the American Orthopedic Society for Sports Medicine Hall of Fame and was named the 2019 Pioneer of Sports Medicine Award winner.

19 Henry J. Mankin, M.D. (October 9, 1928-December 22, 2018) was a Pittsburgh Native, earning both his undergraduate and medical education at the University of Pittsburgh. He went on to become the Edith M. Ashley Professor of Orthopaedics Emeritus at Harvard Medical School and Chair of the Department of Orthopaedic Surgery at Massachusetts General Hospital. Mankin was a pioneer in the field of musculoskeletal oncology. His pioneering research on cartilage and focus on education in Orthopaedic Surgery only begin to highlight the tremendous impact he has had in Orthopaedics.
} 
ma' am, sir, you will feel better tomorrow." So tomorrow, the patient may die or may feel better. Placebo effect.

I had the audacity to look at the placebo effect back in 1986. I became a head doctor at the University of Pittsburgh and when I went to the sidelines, I noticed that there were like 30 oxygen tanks on the sidelines and every player would come out from playing American football and breathe into this oxygen tank. In fact, there was a whole team of people managing oxygen tanks-about 10-15 [people]-that travel with the team. Every team in America was using it. So, we did a study and showed that even in Pittsburgh - with a little polluted air - the oxygen saturation was $99 \%$. So essentially, I tried to remove these oxygen tanks from the sidelines. It took me 10 years. People were unhappy-the coaches, the players-they were convinced that it works. They get the psychological benefit. In fact, the fans were upset with me, some of them wrote me nasty letters. Some of them wrote 'Dr. Fu, our team will lose because you have no oxygen on the sidelines.' But companies are smart. Now they give you hand-held oxygen for $\$ 15$ and they say you will enhance your performance, make you feel better, and everything else. This is really a placebo effect.

Now, orthobiologics is a really good concept: manipulate your blood and re-inject it. It was reserved for sick people, but now people are using it in healthy people. Nobel Prize was given to Professor Donnall Thomas, ${ }^{20}$ essentially for bone marrow transplantation. But now people use a quick fix-PRP, stem cells-they claim that they can cure everything from tennis elbow to hair loss, anything you want, they will have a cure for you. It is a hype. It goes high and then it goes low again, it depends. So, PRP was high maybe 10-15 years ago in America, but now, stem cells seem to have more people enthusiastic about it. So, does PRP work? It seems to work in degenerative joint disease (DJD) and in some cases, tennis elbow, but otherwise it is controversial or unknown whether it works. It definitely doesn't work in the MCL like they talked about. And also, saline works. Maybe by the expansion of the volume, it might stimulate some biological effect.

Stem cells. It is a good idea. We had the first stem cells in the lab in the world in Pittsburgh - it took years to develop $[20,21]$. And we wanted to do it in Orthopaedics, but it was found to be more useful in urology. So, Urologists they use it for stress incontinence. And now it is a big company that

\footnotetext{
${ }^{20}$ Donnall Thomas, M.D. was an American physician, professor emeritus at the University of Washington, and director emeritus of the clinical research division at the Fred Hutchinson Cancer Research Center. In 1990 he shared the Nobel Prize in Physiology or Medicine with Joseph E. Murray for the development of cell and organ transplantation. Thomas and his wife and research partner Dottie Thomas developed bone marrow transplantation as a treatment for leukemia.
}

has \$100 million investment and employs a lot of people and benefits people, and that went through FDA trials and was found to be successful in $85 \%$ of women. Now, if you want to give stem cells to young people, it is silly, because stem cells live everywhere! All along your blood vessels! In young, healthy people, stem cells are everywhere. Your nature will respond to your needs. Moreover, stem cells and cancer cells are not too far apart. In some/many of our [cell] cultures, the stem cells have turned to cancer cells. So, you have to be careful with what exactly you're going to give to the patient. And you can see published in the New England Journal of Medicine, images of a spine after injection of stem cells, became almost like a tumor proliferation [22]. Also, when people were giving stem cells into the eye for macular degeneration, some people went blind because the reaction was so severe! Additionally, a Harvard professor wrote 31 articles claiming that stem cells work for heart attacks. It recovers damaged muscle. Except his study was being challenged and now 31 of his studies are being retracted [23]. The studies were fabricated. The professor was dismissed from Harvard.

Again, this is a 60 min TV episode on CBS, 'review of stem cell fraud in America' (https://www.cbsnews.com/ news/stem-cell-fraud-a-60-minutes-investigation-09-012012/). About 10 years ago, people selling stem cells as a miracle cure for many ailments-multiple sclerosis, back pain-but interestingly, CBS together with patients, looked at the stem cells they received, and many of them had no stem cells at all! They were just dead cells. Now, a company claimed they have a technology where they can keep fresh cartilage allograft alive for much longer than a few days. And they will send you an allograft transplant for $\$ 15,000$ for people with cartilage problems. So actually, we also used it, until my colleague, Dr. Constance Chu, looked at the survival of the cartilage cells, and found that only $7 \%$ were alive [24]. One of the questions is why is there no quality control? We definitely need better quality control.

So, this is from Jim Yong Kim, ${ }^{21}$ who I got to know when he was President of Dartmouth college 'we're making the same mistakes in global healthcare that we make in the American system, believing that better diagnostics and therapeutic tools will solve all problems. They won't. They have not. We don't measure results well enough.' Essentially, the key to anything is really sound outcome measurements; reporting of complications. Everything has an indication, but

\footnotetext{
${ }^{21}$ Jim Yong Kim is an American physician and anthropologist who served as the 12th president of the World Bank from 2012 to 2019. A global health leader, Kim was formerly the chair of the Department of Global Health and Social Medicine at Harvard Medical School and a co-founder and executive director of Partners In Health before serving as the President of Dartmouth College from 2009 to 2012, becoming the first Asian American president of an Ivy League institution.
} 


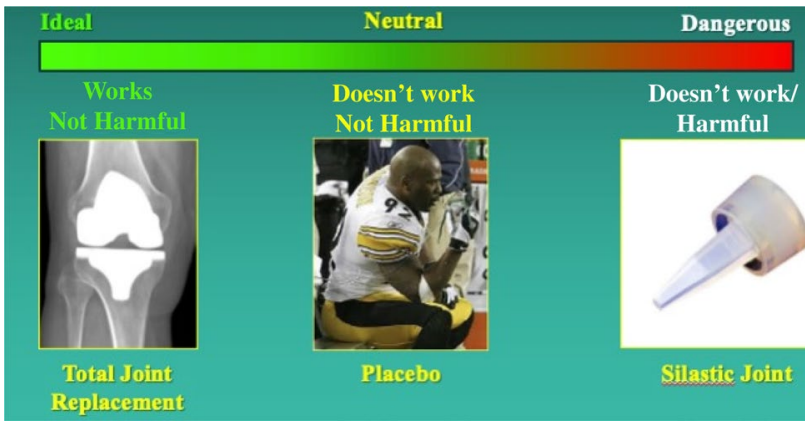

Fig. 4 Three types of products as described by Dr. Freddie Fu

there is not an indication for everything. This is what industry wants, 'You should do it for everything!' Look, industries are fine but we have to remind them 'these are patients, they're not guinea pigs.' Now, polio vaccine, was invented in Pittsburgh by Jonas Salk ${ }^{22}$ with no patent, no interest in personal product and it benefitted the whole world.

I was an AO fellow back in the 1980's. Hanover, Germany provided me a scholarship to study trauma and Maurice Müller ${ }^{23}$ and his colleagues were incredible people. They have an incredible product as well as a philosophy to support and promote research, education, and documentation in the field of medicine, without asking anybody to use the product. I have never been asked by AO to do anything. Free of conflict.

This is the healthcare in the world-US has $18 \%$ GNP [Gross National Product], one of the highest in the world, but in terms of ranking healthcare, America is 27 th-even less now-so not very good. Money does not buy you better healthcare, you have to have quality, you cannot waste money. You have to be value-based. So, do no harm, valuebased, products - there are three types of products (Fig. 4):

Total joint arthroplasty in Orthopaedics, we know it works. We know Oxygen does not work, but it does not harm you, so it will linger for a long time. It may be dangerous because it is going to cost a lot of money without doing anything! And, Silastic implants, for example, does not work AND is harmful, so it drops off......but something new will

\footnotetext{
22 Jonas Salk (October 28, 1914 - June 23, 1995) was an American virologist and medical researcher who developed one of the first successful polio vaccines while conducting research at the University of Pittsburgh School of Medicine.

${ }^{23}$ Maurice Edmond Müller (28 March 1918 - 10 May 2009) was a Swiss orthopedic surgeon who was instrumental in both the development of internal fixation techniques to treat bone fractures and the development of the hip prostheses. The International Society of Orthopaedic Surgery and Traumatology (SICOT) named him the "Orthopedic Surgeon of the Century.".
}

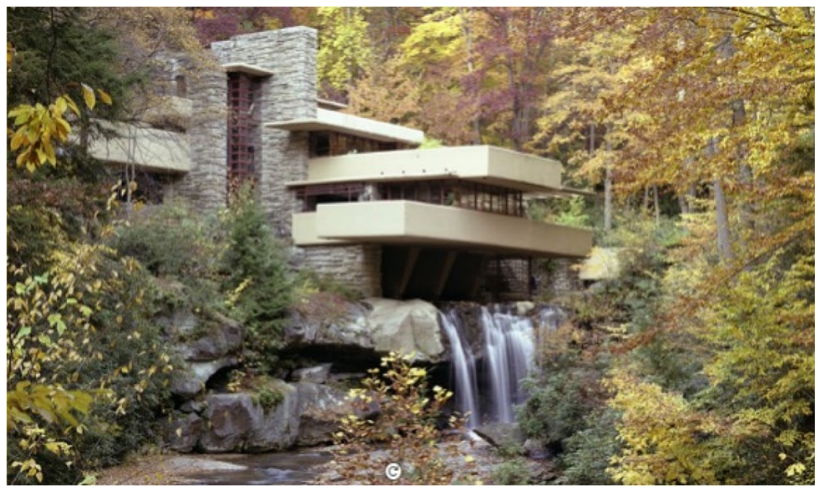

Fig. 5 Falling water-home designed by Frank Lloyd Wright

come back that does the same thing, time after time. Again, these are the things we need to look out for.

Respect and preserve nature. Paul Müller, ${ }^{24}$ a scientist, invented DDT. Essentially, it kills insects and mosquitoes, and is a good idea for controlling the spread of malaria. But problems arise when industry begins to promote its widespread use, worldwide, for everything! Personally, I remember when I was in Hong Kong-I would use DDT in my house all the time to kill cockroaches. So in the end, industry-fueled widespread use of DDT caused a lot of destruction. Rachel Carson wrote a book, Silent Spring, explain how DDT and other insecticides have killed many birds [25]. And because of her, DDT was banned in 1972 and by The World Health Organization (WHO) eventually in 2004 too. In 170 countries (Fig. 5).

At my office along the river-about 2 miles up the office-the American bald eagle returned after 100 years of absence. The American eagle went away because of pollution and DDT. So, when you harm the nature, when you harm the patient, it may never be able to return to normal. So, in nature, nothing exists alone and there is a price we pay if we harm something. OK, so do no harm. "Study nature, love nature, stay close to nature. It will never fail you" This is Frank Lloyd Wright, Falling Water, a beautiful house built around Pittsburgh in 1936. Einstein said "only a life lived for others is worthwhile"-what this means is "you need to look deep into nature, then you will understand everything better. Not just visually, go deeper. '

So as a reminder to everybody: medicine is an art, it is based on scientific principles, you need to understand and work with nature, and you have to respect the past, look at

\footnotetext{
${ }^{24}$ Paul Müller (12 January 1899-13 October 1965) was a Swiss chemist who received the 1948 Nobel prize in Physiology or Medicine for his 1939 discovery of insecticidal qualities and use of DDT in the control of vector diseases such as malaria and yellow fever.
} 


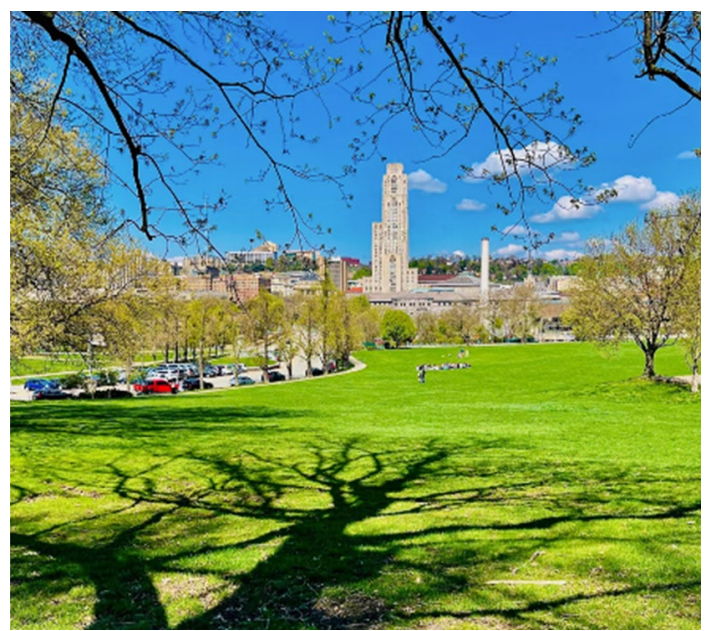

Fig. 6 Picture by Freddie Fu of the cathedral of learning at the University of Pittsburgh

the past, do not repeat the same mistake-so that we can embrace the future. So in conclusion, innovation is necessary for the continued advances in healthcare, however, innovations need to be supported by evidence of both basic science and clinical science. Progress in healthcare requires publication of both positive and negative results. Positive findings must be independently verified. Lastly, learning is forever. This is a picture I took in July 2021 of The University of Pittsburgh campus. You can see a tree with branches and roots. People are talking in the lawn, learning. And far away is the Cathedral of Learning. So, in summary, always learn, importantly, always learn from mistakes (Fig. 6)."

\section{References}

1. Mankin HJ (1982) Current concepts review: the response of articular cartilage to mechanical injury. J Bone Jt Surg Am 64(3):460-466

2. Richmond JC, Donaldson WR, Fu F, Harner CD (1991) Modification of the Bankart reconstruction with a suture anchor. Report of a new technique. Am J Sports Med 19(4):343-346

3. Hill JA, Lombardo SJ, Kerlan RK et al (1981) The modified Bristow-Helfet procedure for recurrent anterior shoulder subluxations and dislocations. Am J Sports Med 9(5):283-287

4. Carroll A (2014) The placebo effect doesn't apply just to pills. The New York Times. Published online 6 Oct 2014

5. Burns JF. German drug maker apologizes to victims of thalidomide. The New York Times. Published online 1 Sept 2012

6. Mukherjee D, Nissen SE, Topol EJ (2001) Risk of cardiovascular events associated with selective COX-2 inhibitors. JAMA 286(8):954-959
7. Swanson AB (1972) Flexible implant resection arthroplasty. Hand $4(2): 119-134$

8. Morrey BF, Askew L, Chao EY (1981) Silastic prosthetic replacement for the radial head. J Bone Jt Surg Am 63(3):454-458

9. Olson EJ, Kang JD, Fu FH, Georgescu HI, Mason GC, Evans $\mathrm{CH}$ (1988) The biochemical and histological effects of artificial ligament wear particles: in vitro and in vivo studies. Am J Sports Med 16(6):558-570

10. Glezos CM, Waller A, Bourke HE, Salmon LJ, Pinczewski LA (2012) Disabling synovitis associated with LARS artificial ligament use in anterior cruciate ligament reconstruction: a case report. Am J Sports Med 40(5):1167-1171

11. Meier BFDA (2013) Seeks to tighten regulation of all-metal hip implants. The New York Times. Published online 16 Jan 2013

12. Corsi KA, Schwarz EM, Mooney DJ, Huard J (2007) Regenerative medicine in orthopaedic surgery. J Orthop Res 25(10):1261-1268

13. Tuan RS (2013) Regenerative medicine in 2012: the coming of age of musculoskeletal tissue engineering. Nat Rev Rheumatol 9(2):74-76

14. Zalavras CG, Gardocki R, Huang E, Stevanovic M, Hedman T, Tibone J (2006) Reconstruction of large rotator cuff tendon defects with porcine small intestinal submucosa in an animal model. J Shoulder Elbow Surg 15(2):224-231

15. Malcarney HL, Bonar F, Murrell GAC (2005) Early inflammatory reaction after rotator cuff repair with a porcine small intestine submucosal implant: a report of 4 cases. Am J Sports Med 33(6):907-911

16. Iannotti JP, Codsi MJ, Kwon YW, Derwin K, Ciccone J, Brems JJ (2006) Porcine small intestine submucosa augmentation of surgical repair of chronic two-tendon rotator cuff tears. A randomized, controlled trial. J Bone Jt Surg Am 88(6):1238-1244

17. Berggren C, Karabag SF (2018) Scientific misconduct at an elite medical institute: the role of competing institutional logics and fragmented control. Res Policy 48(2):428-443

18. Carragee EJ, Baker RM, Benzel EC et al (2012) A biologic without guidelines: the YODA project and the future of bone morphogenetic protein-2 research. Spine J 12(10):877-880

19. United States Senate Finance Committee (2013) Staff report on Medtronic's influence on INFUSE clinical studies. Int J Occup Environ Health 19(2):67-76

20. Lee JY, Peng H, Usas A et al (2002) Enhancement of bone healing based on ex vivo gene therapy using human muscle-derived cells expressing bone morphogenetic protein 2. Hum Gene Ther 13(10):1201-1211

21. Jankowski RJ, Deasy BM, Huard J (2002) Muscle-derived stem cells. Gene Ther 9(10):642-647

22. Berkowitz AL, Miller MB, Mir SA et al (2016) Glioproliferative lesion of the spinal cord as a complication of "stem-cell tourism." N Engl J Med 375(2):196-198

23. Kolata G. Harvard calls for retraction of dozens of studies by noted cardiac researcher. The New York Times. Published online 15 Oct 2018

24. Rohde RS, Studer RK, Chu CR (2004) Mini-pig fresh osteochondral allografts deteriorate after 1 week of cold storage. Clin Orthop Relat Res 427:226-233

25. Carson R (1962) Silent spring. Houghton Mifflin Company, Cambridge

Publisher's Note Springer Nature remains neutral with regard to jurisdictional claims in published maps and institutional affiliations. 